【論文】

\author{
大規模土工の施工計画プロセスの \\ システム化に関する研究
}

\title{
STUDY ON A SYSTEMS APPROACH TO CONSTRUCTION PLANNING PROCESS OF LARGE-SCALE EARTH-MOVING
}

\author{
吉 川和 広* ・山本 幸 司** \\ By Kazuhiro YOSHIKAWA and Koshi YAMAMOTO
}

\section{1. 緒 言}

近年, 工事規模の桩大および工事内容の多様化・複雑 化に対処するため, 特殊工法の開発や大規模な機械化施 工の導入に代表される施工技術（いわばハード・テク） ロジー）はめざましい進展をみせているが, 工事施工の 確実性・迅速性・経済性を詳細倹討する施工計画・管 理方法の確立をめざすソフト・テクノロジーの立ち遅れ が指摘され，その充実化が叫ばれている。しかしなが ら, 注文生産・属地生産・一品生産といら土木工事の特

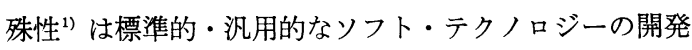
を遅らせ, 技術者個人の経験・勘に基づく主観的判断に 依存するところが大であったのが従来の傾向である.

そこで，筆者らは，基本的な作業の連続にもかかわら ず関連する計画要素が複雑かつ多様なために, 体系化・ 標準化が遅れている大規模機械化土工を事例として取上 げ,その施工計画作成プロセスのシステム化を試み,「整 地工事計画システム」(旧システム)を提案した ${ }^{2)}$. 本研究 はこれを修正・発展させた成果を「大規模土工の施工計 画システム」(新システム) として提案するものである. 前述したような土木工事の特殊性を考慮すれば，大規 模土工の施工計画に含まれるすべてのプロセスをハード 化（電算化）することは不可能であり, 全体としてはマ ン・マシン・システム的なソフトな計画システムとして 開発せざるをえないが, 客観的かつシステマティックな 評価体系を備えた計画システムとするためには，技術 者個人の経験あるいは勘に依存していた計画策定手順に 対して各種 $\mathrm{OR}$ 手法の遒入を試み，できる限りハード 化していくことを考えなければならない.この意図か ら, 旧システムでは, 線形計画法, モンテカルロ・シミ ュレーション手法, ネットワーク手法の導入を試みた

* 正会員 工博 京都大学教授 工学部土木工学教室 ** 正会員 工博 京都大学助手 工学部土木工学教室
が，作業計画および工程計画のプロセスに関しては技術 者個人の主観的判断に基づく試行錯誤的なアプローチの 域を脱しきれず, 計画システム全体としての整合性の追 求および客観的評価体系の確立といら目的に対しては不 十分であった.

そこで本研究では, 作業計画プロセスのらちの単位作 業（実施工の作業ユニット）の決定プロセスに対してク ラスター分析の適用を, また土工機械系の割付けプロセ スに対しては拡張型輸送問題の適用を試みた. その結 果, 新システムでは各計画プロセス相互間のインプット 情報とアウトプット情報が有機的に結合し, 計画システ ムとしての整合性をかなり改善することができた.

以下，2.では旧システムと比較しながら 新システム の概要を述べ，3. では作業計画および工程計画の対象 となる作業単位の決定ならびに施工工区割りに対してク ラスター分析を適用する方法を提案し， 4. では各作業 単位への土工機械系の割付けプロセスに対して挔張型輸 送問題を適用する方法論を提案する.

\section{2. 大規模土エの施工計画システム}

本研究で 提案する大規模土工の 施工計画システムは 図一1に示すように, 設計仕様および現場施工条件など を入力情報とし, 土量配分方法, 土工機械系の割付け方 法, 工程ネットワークの作成方法などを操作変数とし て, 施工手順, 工事所要日数, 工事所要費用など, 工事 を具体的に実施するために必要な諸情報を出力するシス テムであり，その概要は以下に示すとおりである.

\section{（1）計画への入カプロセス}

これは, 本システムへの入力情報として自然情報・設 計情報・社会情報を作成し, その内容を検討するプロセ スであるが, 本研究では工事発注者と工事受注者が別組 織体に属する場合を想定し, 施工計画作成段階ではこれ 


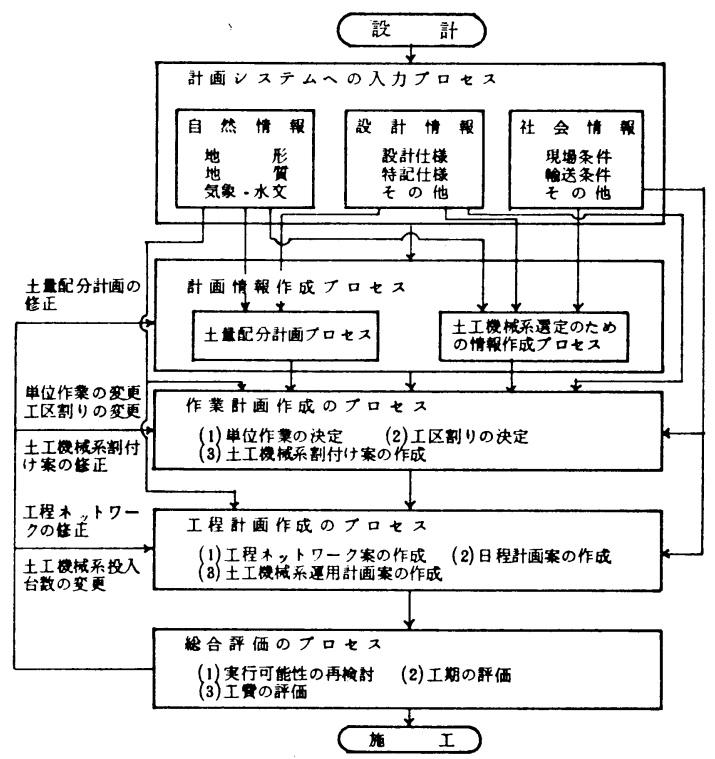

図一1 大規模土工の施工計画システムの プロセスフロー

らの内容を与件として扱うことにする. したがって, 総 合評価のプロセスからのフィードバックも考慮しない.

\section{（2）計画情報作成のプロセス}

これは本システムの核となる作業計画と工程計画に対 する計画情報を作成するプロセスで, 土量配分計画プロ セスと土工機械系の選定情報作成プロセスとによって構 成される.

a）土量配分計画プロセス

本研究では, 大規模土工に不可欠なブルドーザの稼働 特性を考慮して施工区域を一辺 50〜 $80 \mathrm{~m}$ 程度の施工ブ ロックに分割し, 次のような土量配分計画モデルによっ て搬土計画を策定するとともに, 距離別運土量, 土質別 運土量などをアウトプットするプロセスを考えた.

$$
\begin{aligned}
& z=\sum_{i=1}^{m} \sum_{j=1}^{n} d_{i j} x_{i j} \rightarrow \min \ldots \ldots . . . \\
& \sum_{j=1}^{n} x_{i j}=C_{i} a_{i} \\
& \sum_{i=1}^{m} x_{i j}=b_{j} \\
& \sum_{i=1}^{m} \sum_{j=1}^{n} x_{i j}=\sum_{i=1}^{m} C_{i} a_{i}=\sum_{j=1}^{n} b_{j} \\
& x_{i j} \geq 0
\end{aligned}
$$

ここに, $d_{i j}$ : 切土ブロック $i$ から盛土ブロック $j$ ま での運土距離 $(\mathrm{m}), x_{i j}$ : 締固め状態に換算した 運土量 $\left(\mathrm{m}^{3}\right), C_{i}$ : 切土ブロック $i$ の土量変化率 $C, a_{i}$ : 地山 状態での切土ブロック $i$ の切土量 $\left(\mathrm{m}^{3}\right), b_{j}$ : 締固め状 態での盛土ブロック $j$ の盛土量 $\left(\mathrm{m}^{3}\right)$ であり, $m$ は切 土ブロック数, $n$ は盛土ブロック数である.
式 (1), (2) によって仕事量 $z$ を最小とする搬土計画 $\left\{x_{i j}\right\}$ が得られるが, 実際の積載運土量（ほぐした状態 の土量) $v_{i j}$ は,

$$
v_{i j}=\left(L_{i} / C_{i}\right) \times x_{i j}
$$

として算定される. ここに， $L_{i}$ : 切土ブロック $i$ の土 量変化率 $L$ である.

なお，運土費用を目的関数とする考え方もあるが3)， 土工機械系の運用スケジュールを考虑できない土量配分 計画の段階で各運土作業に対して特定の土工機械系を割 付けなければならない土量配分計画モデルは, 結果的に 工期の遅延や工費の増大を招く可能性が大きく，あまり 合理的な方法とはいえない.

また，ほぐした状態の土量を直接変数とする土量配分 計画モデルも可能であるが，この場合には式 (1)，(2) のような古典的輸送問題ではなく抬張型輸送問題として の定式化となる.

b）土工機械系の選定情報作成プロセス

これは各運土作業に対して最も経済的な土工機械系を 選定するために, 当該工事の施工条件と各種土工機械系 の稼働特性との関係を分析するプロセスである.

土工機械系の稼働状況を分析する方法としては, 待ち 合わせ理論（特にサイクルキューモデル）を適用する方 法とシステムシミュレーションによる方法とが考えられ た. 前者に関しては作業時間をアーラン分布で近似する アーランサービスサイクルキューモデルの解析法を提案 したが4)，本論文で対象とする土工工事では土工機械系 の稼働状況が複雑で, 待ち合わせ理論では十分にモデル 化しえないことが明らかとなったため，モンテカルロシ ミュレーション手法を採用した. その結果，いくつかの 土工機械系について運土距離と運土単価との関係, 運土 距離と所要作業時間との関係などが得られたが5), その

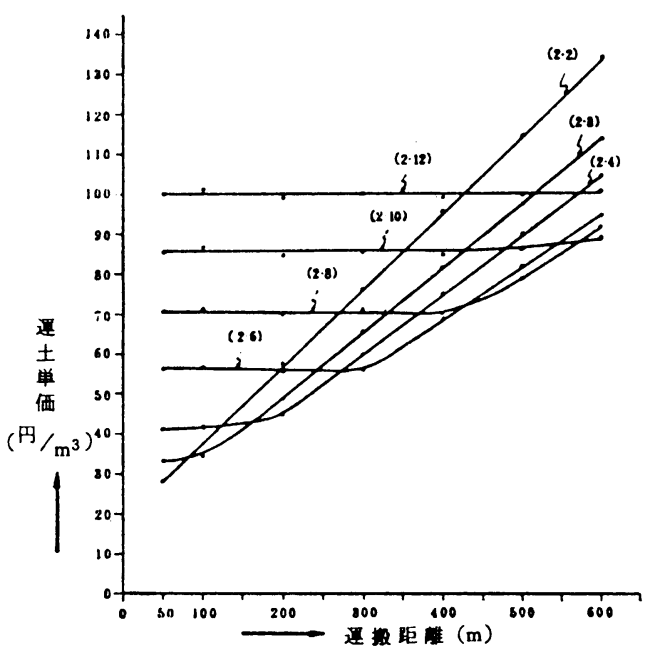

図一2 運土距離と運土単価との関係 
一例を示したのが 図一2 である.

\section{（3）作業計画作成のプロセス}

これは土量配分計画の結果を利用して実施工の対象と なる単位作業を決定し，それらに土工機械系を割付け， さらに単位作業ごとの所要工事費用および所要工事日数 を概算するプロセスである.

土工機械系の稼㗢特性を考慮すれば，土量配分計画と して得られる個々の運土作業を作業単位として扱らには 土工量が少なすぎ，このままでは作業工程が非常に複雑 なものになる，そこで，施工条件が類似した隣接作業を ある程度の大きさに統合することを考え，これを実施工 の作業単位（以下では単位作業とよぶ）として扱うこと にした.

この問題に関して旧システムでは必要な諸要件（土量 配分計画, 工事障害物, 計画地形の概要など)を記載した 原地形闵上で運土作業の作業状況をシミュレートしなが ら試行錯誤的に単位作業を想定し，ついで図一2のよう な土工機械系の選定情報を利用して各単位作業ごとに最 適な土工機械系を割付け，その所要時間および所要費用 を算定する方法を提案した・しかしこのような方法では，

(1) 図上でのシミュレーションであるため計画担当者 の主観的判断が働きやすく, 計画代替案を具体的に記述 し, 客観的に評価検討するのが困難であること，

(2) 土工機械系の割付けにあたって, 投入可能な土工 機械台数の制約を直接考虑することができないこと，

(3) 1 つの単位作業は必ず 1 つの土工機械系で施工し なければならなくなること，

などの問題点を生じた．そこで新システムではこれらの 問題点を解決するために, 単位作業の決定に関してはク ラスター分析の導入を, また土工機械系の割付けに関し ては拡張型輸送問題による機械系割付けモデルの導入を 提案する.

\section{（4）工程計画作成のプロセス}

これは単位作業をアクティビティとする工程ネットワ 一ク代替案を作成し, それ対して日程計画および土工 機械系の運用計画などを策定するプロセスである.

旧システムでは PERT/MANPOWER によって日程 計画を作成したが, 新システムではクラスター分析や拡 張型輸送問題を導入した作業計画のプロセスと一体化し た工程計画作成プロセスを考える.

\section{（5）総合評価のプロセス}

一般に, 施工計画の 評価基準 としては確実性・迅速 性・経済性が考えられるが，施工計画を作成する段階で は確実性を表現する計画要素の定量化およびその具体的
な評価検討が困難であり, 施工計画作成の段階よりもむ しろ実施工の段階で詳細に検討すべきであることを考慮 して, 本研究では確実性を取り扱わないこととする.

したがって，本プロセスでは，(i) 土工工事の実行可 能性が十分に保証されるかどうかを検討し，続いて (ii) 工事所要日数が所与の工期内に十分納まるか, (iii) 工 事所要費用が十分に低廉か，とい5 3 つの評価基準によ って計画代替案を総合的に評価し, 最終的に 1 つの実施 計画案を選択することになる，そして，作成した代替案 の目的達成度が低いと判断される場合には, その内容に 応じて 図一1 に示したように各計画プロセスへのフィ ードバックを考えるものとする.

なお，式 (1)，(2) のような土量配分計画モデルを前 提とし, 設計情報や土質条件等の入力プロセスからの情 報を与件とする限り, 土量配分計画プロセスヘフィード バックする必要性は少ないが，たとえば部分的に生じた 長距離土工が工費の 増大化の一因となっている場合に は, 関連する運土作業の運土距離に制限を設けて土量配 分計画を修正することも考慮しなければならない。

\section{3. クラスター分析を導入した単位作業の決定 ${ }^{6}$}

\section{（1） 概 説}

土量配分計画プロセスでは仕事量が最小となる搬土計 画が得られるが，土量配分計画を作成する段階では運搬 経路や施工順序，作業段取りなどを計画情報として具体 的かつ十分に検討することが困難であるため, 土量配分 計画の結果を直接用いて実施工程計画を作成するという 計画作成方法は問題が多いといわざるを得ない。また, 工程計画の作成において, 土工機械系の輻輳の軽減, 作 業段取り手順および機械系運用計画の簡略化などを目的 とすれば，すでに述べたようにもら少し大きな作業ユニ ットを計画対象とすることが望ましいと考えられる.

そこで，土量配分計画として得られる各運土作業の作 業特性をいくつかの要因によって客観的に記述し，それ を用いて運土作業間の類似度を定量的に把握すれば, 類 似度の高い運土作業を順次統合することによって実施工 の対象となる作業ユニット (単位作業) を決定すること ができる. 本研究ではこのような計画プロセスに対して クラスター分析手法の導入を試みる。これによって土量 配分計画と作業計画・工程計画との間の整合性を保つこ とが可能となるとともに, クラスター分析のデンドログ ラムは当該工事区域を工区分割するための計画情報とし て有効に利用することができる.

\section{（2）クラスター分析モデルの作成}


クラスター分析は因子分析の前処理プロセスとしてホ ールジンガーによって提案された数值分類法であるが, 分析対象の各個体（ここでは運土作業）の特性を表現す るいくつかの要因を抽出し，その特性值によって個体を 分類するという機能に着目すれば,「似た者どうし」を 統合する手法としても有効である7).

そこで，まず運土作業の作業特性を表わす要因につい て 検討した 結果, (1) 当該運土作業の 切土地点の 座 標 (始点座標), (2) 盛土地点の座標 (終点座標), (3) 運土 方向, (4) 運土距離, (5) 運土量という5 項目を考えてい くことにした.なお，これら以外にも土質条件（盛土材 として適さない土質を含む場合）や障害物の有無, 運土 勾配などが考えられたが，これらはクラスター分析モデ ルから除外し必要に応じて別途に検討することにした.

このような 5 要因を記述するためには各運土作業 $i を$ 次式のような特性值 $P_{i}$ で表わせば十分である.

$$
P_{i}=\left(x_{i_{1}}, y_{i_{1}}, x_{i_{2}}, y_{i_{2}}, v_{i}\right)
$$

ここに, $x_{i_{1}}, y_{i_{1}}$ : 運土作業 $i$ の始点の $x$ 座標および $y$ 座標, $x_{i_{2}}, y_{i_{2}}$ : 終点の $x$ 座標および $y$ 座標, $v_{i}$ : 運 土量であり，その值はすべて土量配分計画のアウトプッ トとして得られる.これらの変数を用いることにより, 任意の 運土作業 $i, j$ 間の各要因間距離, 寸なわち始点 間距離 $S D_{i j}$, 終点間距離 $E D_{i j}$, 方向間距離 $W D_{i j}$, 運土距離間距離 $D D_{i j}$ ，および運土量間距離 $V D_{i j}$ は 次式によって算出することができる（図一3 参照).

$$
\begin{aligned}
& S D_{i j}=\sqrt{\left(x_{i_{1}}-x_{j_{1}}\right)^{2}+\left(y_{i_{1}}-y_{j_{1}}\right)^{2}} \cdots \cdots \cdots(5) \\
& E D_{i j}=\sqrt{\left(x_{i_{2}}-x_{j_{2}}\right)^{2}+\left(y_{i_{2}}-y_{j_{2}}\right)^{2}} \cdots \cdots \cdots(6) \\
& W D_{i j}=2 \arcsin \left(\frac{\sqrt{\left(r_{i_{1}}-r_{j_{1}}\right)^{2}+\left(r_{i 2}-r_{j_{2}}\right)^{2}}}{2}\right)
\end{aligned}
$$

ただし，

$$
\begin{aligned}
& r_{\cdot 1}=\frac{x_{\cdot 2}-x_{\cdot 1}}{\sqrt{\left(x_{\cdot_{1}}-x_{\cdot_{2}}\right)^{2}+\left(y_{\cdot_{1}}-y_{\cdot 2}\right)^{2}}} \\
& r_{\cdot 2}=\frac{y_{\cdot 2}-y_{\cdot 1}}{\sqrt{\left(x_{\cdot_{1}}-x_{\cdot_{2}}\right)^{2}+\left(y_{\cdot_{1}}-y_{\cdot_{2}}\right)^{2}}} \\
& D D_{i j}=\mid \sqrt{\left(x_{i_{1}}-x_{i_{2}}\right)^{2}+\left(y_{i_{1}}-y_{i_{2}}\right)^{2}} \\
& -\sqrt{\left(x_{j_{1}}-x_{j_{2}}\right)^{2}+\left(y_{j_{1}}-y_{j_{2}}\right)^{2}} \mid \cdots \cdots(8) \\
& V D_{i j}=\min \left\{v_{i}, v_{j}\right\}
\end{aligned}
$$

ここで, 方向間距離 $W D_{i j}$ は, 運土作業 $i$ と $j$ の始

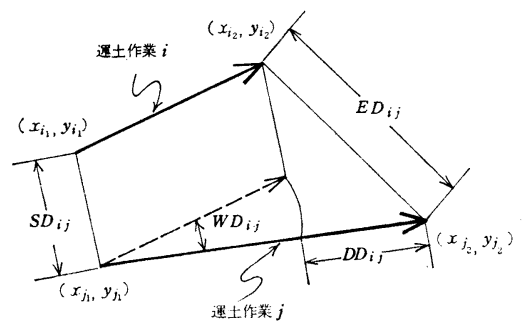

図一3 各要因間距離
点を一致させたのち運土距離を正規化したときの終点閒 座標が運土作業 $i$ と $j$ の運土方向の夾角と一致するこ とを利用して求めた值である. また運土量間距離 $V D_{i j}$ は運土量の少ない運土作業をできるだけ他の運土作業に 統合させ，作業段取りを簡略化することを考慮したもの である.

以上の結果を利用すれば, 運土作業 $i$ と $j$ の類似度 を次のような距離 $d_{i j}$ として表わすことができる.

$$
\begin{aligned}
d_{i j}= & k_{1} \cdot S D_{i j}+k_{2} \cdot E D_{i j}+k_{3} \cdot W D_{i j} \\
& +k_{4} \cdot D D_{i j}+k_{5} \cdot V D_{i j} \ldots \ldots \ldots \ldots \ldots . . .
\end{aligned}
$$

ここに, $k$ は各要因間距離の相対的重み倸数であり, こ れを正確に表現するためには上式の右辺各項をそれぞれ の最大距離で割って正規化しておくことが望ましい.

さて, 具体的なクラスター形成方法に関しては数多く の手法が提案されているが，ここでは，

(1) 単位作業の決定上, 1 つのクラスターとして結合 した個体が次段階以降に当該クラスターからとび出して 他のクラスターと結合することは好ましくないことから 階層的手法であること，

(2) 単位作業間の施工順序づけに必要な情報を得るた めには, 多くの個体が同時に 1 つのクラスターとして結 合する方法は好ましくないこと，

などを考慮した結果, WPG 法を導入することにした.

WPG 法とは, 個体（もしくはクラスター, 以下同様） $i$ から最短距離にある要素が個体 $j$ であるときに, 同じ く個体 $j$ から最短距離にある要素が個体 $i$ であるとき, $i$ と $j$ を 1 のラスターとして 結合させる方法であ る ${ }^{8)}$. 実際の計算過程では, クラスター形成サイクルが 終了するごとに各個体間の 距離を修正する必要がある が, その前処理として, 本研究では新しく形成されたク ラスターの特性を表わす要因として運土量を重みとする 重みつき平均を考えた. すなわち, 個体 $\alpha$ と $\beta$ が 1 つの クラスター $r$ として結合したとき, $r$ の始点座標 $\left(x_{r_{1}}\right.$, $\left.y_{r_{1}}\right)$ は,

$$
\left.\begin{array}{l}
x_{r_{1}}=\frac{v_{\alpha} x_{\alpha_{1}}+v_{\beta} x_{\beta_{1}}}{v_{\alpha}+v_{\beta}} \\
y_{r_{1}}=\frac{v_{\alpha} y_{\alpha_{1}}+v_{\beta} y_{\beta_{1}}}{v_{\alpha}+v_{\beta}}
\end{array}\right\}
$$

となる. なお, 終点座標 $\left(x_{r_{2}}, y_{r_{2}}\right)$ に関しても同様で ある・

\section{（3）単位作業および工区分割の決定}

クラスター分析モデルによって単位作業を決定し, さ らに施工工区割りを検討するためには以下のような $2 つ$ の問題点について十分に考察しておく必要がある.

そのひとつは式（10）の重み係数の決定方法に関する 問題である.これに関しては理論的な算定方法が存在し ないため, 各要因の重み係数をパラメトリックに変更し 
て計算を実行し,その結果得られるクラスター形成過程 を検討することによって経験的, 恣意的に決定せざるを 得ない, 本研究は過去の経験や勘に頼るのではなく, 客 観的かつシステマティックな評価に基づく意志決定を研 究目的とするものであるが，重み係数の決定に関しては 現場技術者の経験・勘を計画情報として利用することと した．その方法については次節で述べることにする.

他方はどの段階のクラスターを基準として単位作業な らびに工区割りを決定すればよいかという問題である. しかしこれに関しても理論的な判断基準が存在しないた め，まず現場技術者にヒヤリング調查を実施したとこ ろ，一辺 $50 \mathrm{~m}$ の施工ブロックを対象とする土量配分計 画の場合には作業管理上たかだか 2 4 個の運土作業を 統合した 程度の 作業単位が 適当であると判断された. そこで, 本研究では第 2 サイクルまでにおいて形成され るクラスターを基準として単位作業を決定することにし た.これは, 第 $n$ サイクルではたかだか $2^{n}$ 個の個体 がひとつのクラスターを形成しらるという WPG 法の 特徴に基ゔく結果である.

なお，工区分割に関しては，まず工事規模や総土工量 を考慮して工事区域を何工区に分割すべきかを判断し， その個数に合ったクラスターを生成するサイクルに着目 寸ればよいことになる.

\section{(4) 適用事例とその考察}

本節では, クラスター分析モデルを用いて単位作業を 決定する計画プロセスの 適用事例として 表一1 に示す

\section{表-1 適用事例工事の概要}

\begin{tabular}{c|c}
\hline 工 事 面 積 & 約 39 万 $\mathrm{m}^{2}$ \\
\hline 総 連 土 量 & 約 130 万 $\mathrm{m}^{3}$ \\
\hline 土量変化率 & $C=1.0, L=1.25$ \\
\hline 原地盤最大高低差 & $40 \mathrm{~m}$ \\
\hline 施エフロックサイス & $50 \mathrm{~m} \times 50 \mathrm{~m}$ \\
\hline 切土フロック数 & 77 個 \\
\hline 盛 エフロック数 & 87 個 \\
\hline
\end{tabular}

ような内容の土工 工事を取上げ，実 証的考察を行うこ ととする.なお, 当該工事の土量配 分計画図を示した のが図-4であ る.

まず，当該現場
の施工技術者に対してヒヤリング調查を実施した結果, 実施工の作業単位を決定する際には始点間距離および終 点間距離を特に重視する必要があるなどの情報が得られ たため,これをもとにして重み係数の組合せパターンを パラメーターとしてクラスター分析を行った. そしてこ れとは別に，数人の施工技術者に適用事例工事の内容を 示し, 各人の経験に基ついて単位作業を決定してもらっ たところ, その内容は $\left(k_{1}: k_{2}: k_{3}: k_{4}: k_{5}\right)=(25: 10:$ $3: 1: 1)$ といら重み係数パターンによる分析結果と一 致することが明らかとなった。

ここでは，クラスター分析モデルのインプットデータ

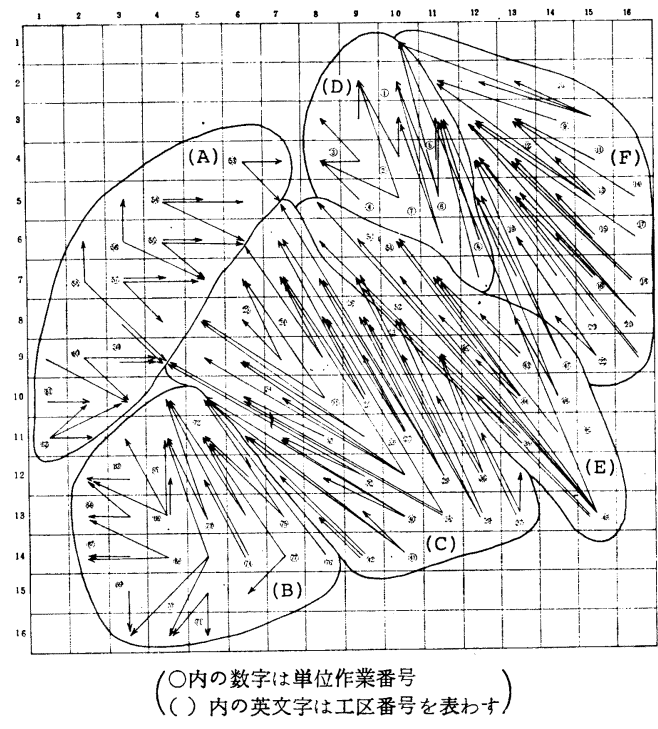

図一4 土量配分計画図（単位作業および工区割り案）

および計算結果のデンドログラムの記述を割愛し, 単位 作業の構成状況 および工区分割の結果を 図一4 上に示 すにとどめる. なお，当該工事では機械化土工の障害と なる物件は存在しなかった。

本研究では当該工事とは施工条件の異なる数現場に対 してもクラスター分析の適用を試みたが, その結果次の ような事柄が明らかとなった.

(1) 土質条件, 障害物の有無, 運土勾配をクラスター 分析モデルの要因として盛込まなければ, 工事条件の異 なる現場に対しても（25:10:3:1:1）といら重み係 数パターンが適当である. したがって始点間距離および 終点間距離に対するウエイトが非常に大きいといえる.

(2) 土量配分計画として得られる各運土作業の仕事量 の総和 (目的関数值) とクラスター分析モデルによって 作成した 各単位作業の仕事量の 総和との差異は $0.01 \%$ 以下であった. このことから, 土量配分計画と単位作業 決定プロセスとの間の整合性がある程度保証できるもの と考えられる.

以上の結果より, 本クラスター分析モデルは土量配分 計画との整合性を保ちつつ, 実施工の対象となる作業単 位を客観的かつシステマティックに決定するための手段 として有効に機能することが明らかとなった.

\section{4. 拡張型輸送問題による土工機械系の割付け 計画 $^{9)}$}

(1) 概 説

経済性および迅速性の追求，作業効率の向上等は機械 化施工導入の主要目的と考えられるが，機械経費が全工 
事費に占める比率が大きな大規模土工ではとりわけ経済 性の追求が重要視される. したがって, 大規模土工の施 工計画システムとしても機械経費を極力低隇化するよう な計画策定方法を提案する必要がある. 一般に機械化土 工の機械経費 $z$ (円）は, 式（12）に示すように稼働時 間に比例する経費と, 供用日数に比例する経費, および これらに無関係な固定経費によって構成される ${ }^{10)}$.

$$
z=\left(\sum_{i} c_{i} h_{i}+\sum_{i} d_{i} t_{i}+\sum_{i} P_{i}+q\right) \cdot(1+S / 100)
$$

ここに, $c_{i}$ : 土工機械系 $i$ の稼働時間当り機械経費 (円 / 時), $h_{i}$ : 総稼働時間 (時), $d_{i}$ : 供用日当りの機械経 費 (円 $/$ 日), $t_{i}$ : 供用日数 (日), $P_{i}$ : 輸送費等の固定経 費 (円), $q$ : 仮設備等の固定経費 (円), $S:$ 工事諸経費 率 (\%) である.このうち $c_{i}$ および $d_{i}$ は, $c_{i}=\{$ 購入価格 $\times(0.5 \times$ 償却費 + 定期整備費率 十現場修理費率)/耐用時間 $\}+$ 運転経費

$d_{i}=\{$ 購入価格 $\times(0.5 \times$ 償却費 + 年間機㳦管理費率 $\times$ 耐用年数 $)\} /$ (年間標潐供用日数 $\times$ 耐用年数 $)$

と算定されるのが一般的である ${ }^{11)}$.

式 (12) に扔いて， $c_{i}, d_{i}, P_{i}$ は投入する機械系の機 種抢よび台数に固有な值であり, $q, S$ は当該工事に固 有な值であることから，機械経費 $z$ の最小化は次式の 機械経費 $z^{\prime}$ の最小化と同義となる.

$$
z^{\prime}=\sum_{i}\left(c_{i} h_{i}+d_{i} t_{i}\right)
$$

ここで, $D_{i}$ : 土工機械系 $i$ の稼働日当りの標準稼働時間 (時間 $/$ 日), $\hat{t}_{i}$ : 供用日数 $t_{i}$ の 5 万実稼㗢日数 (日), $\bar{t}_{i}: t_{i}$ のうちの作業不能日数（現場整備日数や休日㧤よ び天候の影響など) (日), $r_{i}: t_{i}$ のうちの遊休日数 (日)， $\alpha_{i}$ : 作業不能日数率, $\beta_{i}$ : 遊休日数率を考えると, $h_{i}$ お よび $t_{i}$ は次のように表わすことができる.

$$
\begin{aligned}
& h_{i}=D_{i} \cdot \hat{t}_{i} \\
& t_{i}=\hat{t}_{i}+\bar{t}_{i}+r_{i}=\hat{t}_{i}\left(1+\alpha_{i}+\beta_{i}\right)
\end{aligned}
$$

式 (15), (17) より $r_{i}$ を極力小さくするような土工機 械系割付け計画および日程計画が望ましいことは明らか であるが，現実には工事現場の規模や地形条件, 施工上 の技術的条件, 投入土工機械系の性能および台数などが 影響して必然的な遊休日数 $r_{i}$ が発生する. そこで, 土 工機械系割付け計画のプロセスにおいて遊休日数 $r_{i}$ を どの程度考慮すべきかといら問題が生じるが，この值は 土工機械系割付け計画をもとにして日程計画案を策定し た後において初めて明らかになるため, 式 (15) の $z^{\prime}$ を直接評価基準とする土工機械系割付け計画は不合理で ある. そこで，次節では日程計画と有機的に結合する土 工機械系割付け計画を考えていくことにする.

\section{（2）拡張型輸送問題による土工機械系割付け計画}

a) 機械系割付けモデル

いま，すべての投入機械系 $i(\in I)$ に対して遊休日数 $r_{i}$ を 0 と仮定すれば，式 (16)，(17) より，

$$
t_{i}=\left(1+\alpha_{i}\right) \hat{t}_{i}=\left(1+\alpha_{i}\right) h_{i} / D_{i}
$$

となる．このような条件下での機械経費 $z^{\prime}$ を新たに $z_{1}$ とおくと, 式（18）を式（15）へ代入することによって，

$$
z_{1}=\sum_{i}\left\{c_{i}+\left(1+\alpha_{i}\right) d_{i} / D_{i}\right\} h_{i} \cdots
$$

となる.したがって, 各機械系 $i$ の遊休日数 $r_{i}$ を無視 したときの土工機械系割付け計画は次のように定式化で きる. 以下ではこれを機械系割付けモデルとよぶ.

$$
\begin{aligned}
z_{1} & =\sum_{i=1}^{m}\left\{c_{i}+\left(1+\alpha_{i}\right) d_{i} / D_{i}\right\} h_{i} \\
& =\sum_{i=1}^{m} \sum_{j=1}^{n}\left\{c_{i}+\left(1+\alpha_{i}\right) d_{i} / D_{i}\right\}\left(n_{i j} / N_{i j}\right) \rightarrow \min
\end{aligned}
$$

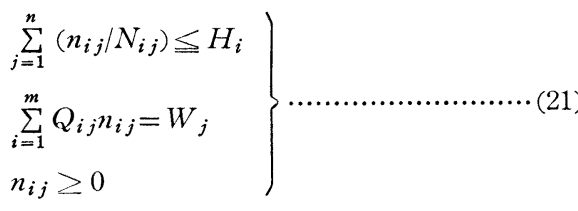

ここに, $n_{i j}$ : 単位作業 $j$ のうち土工機械系 $i$ で施工す る運土回数 (回), $N_{i j}$ : その時間当り運土回数 (回/時), $Q_{i j}$ : その積載容量 $\left(\mathrm{m}^{3} /\right.$ 回 $), H_{i}$ : 土工機械系 $i$ の総稼 働可能時間 (時間), $W_{j}$ : 単位作業 $j$ の運土量, $m$ : 投 入機械系数, $n$ : 単位作業数である.

条件式 (21) の第 1 式は各土工機械系の総稼働時間に 関する制約であり，第 2 式は各単位作業の土工量に関す る制約である．また条件式（21）に着目すれば，この機 械系割付けモデルは拡張型輸送問題と考えられるため, 㹡張型飛び石伝い法によって効率よく解くことができ $ろ^{12)} 1^{14)}$.

ところで, 運土回数 $n_{i j}$ は本来整数型変数であるが, この定式化では便宜上実数型変数として扱ったため, こ のような処置が土工機械系割付け計画におよぼす影響に ついて検討する必要がある.これに関しては， $\left[n_{i j}\right]$ : $n_{i j}$ の整数部 (回), $Q_{i j}{ }^{\prime}$ : 積土板等の設置による超過積 載可能量 $\left(\mathrm{m}^{3} /\right.$ 回) を考えたとき,

$$
Q_{i j} \times\left(n_{i j}-\left[n_{i j}\right]\right) \leqq Q_{i j}{ }^{\prime} \times\left[n_{i j}\right] \cdots
$$

が成立すれば, $n_{i j}$ 回分の運土量を $\left[n_{i j}\right]$ 回の運土作業 で処理できることを意味する．そこで，いま $Q_{i j}{ }^{\prime}=0.2$ $Q_{i j}$ と仮定すれば式 (22) は,

$$
\left[n_{i j}\right] \geqq n_{i j} / 1.2
$$

となり，これより $n_{i j} \geqq 5.0$ ならば必ず式 (22) が成立 する.本研究で対象とするような大規模土工では式 (23) が十分に成立すると判断できるため, 本研究では式 
(20)，(21）の機械系割付けモデルの最適解の少数部分を 切捨てることによって土工機械系割付け計画 $\left\{n_{i}{ }^{\circ}\right\}$ を 策定することにする. このとき, 土工機械系 $i$ の稼働時 間 $h_{i}{ }^{o}$ および供用日数 $t_{i}{ }^{o}$ は次式によって算定される.

$$
\left.\begin{array}{l}
h_{i}^{o}=n_{i j}{ }^{o} / N_{i j} \\
t_{i}^{o}=\left(1+\alpha_{i}\right) h_{i}^{o} / D_{i}=h_{i}^{o} / D_{i}+\bar{t}_{i}^{o}=\hat{t}_{i}^{o}+\bar{t}_{i}^{o}
\end{array}\right\}
$$

b） 単位作業をアクティビティとする日程計画 前節で示した機械系割付けモデルは, 便宜上遊休日数 $r_{i}$ を0と仮定するものであった. したがって,この結果 をそのまま用いて日程計画を作成すると必然的に遊休日 数が発生するため, 工期的に実行不可能となる場合も考 えられる.そこで, 本節では土工機械系割付け計画の計 算結果を利用して実行可能な日程計画を策定する方法を 提案することとする.

まず, 工程ネットワークの作成に関しては, 各単位作 業の施工順序決定上の自由度が大きすぎるため 2 段階に 分け, 最初に施工工区レベルでの施工順序関係を検討し ついで土工機械系の運用を十分に考慮しながら個々の施 工工区内の各単位作業に対する順序関係を検討する方法 を考えた．その内容に関しては次節で触れることとし， 本節では 1 つの日程計画代替案が策定できたものとして 以下の議論を行う.

一般に, 土工機械系 $i$ の供用日数と供用可能日数との 間には 図一5 に示すような関係が存在する. 図中, $\hat{T}_{i}$ : 土工機械系 $i$ の実稼働可能日数, $\bar{T}_{i}: \bar{t}_{i}$ と同様の考え方 に基づく作業不能日数 $\left(=\alpha_{i} \hat{T}_{i}\right), T_{i}:$ 土工機械系 $i$ の 遊休に対する余裕日数 $R_{i}$ を含む供用可能日数, $\tilde{T}_{i}$ : 工事着工日から土工機械系 $i$ の現場搬入日までの日数, $T^{*}$ : 当該工事の機械化土工実施可能日数である.

したがって,いま土工機械系割付け計画案 $\left\{n_{i j}{ }^{o}\right\}$ を用 いて策定した日程計画案に基づいて, 各土工機械系 $i$ の 運用計画を策定したときに生じる遊休日数を $r_{i}{ }^{\circ}$ とおい たとき, まず土工機械系 $i$ が供用可能であるためには,

$$
t_{i}=\left(t_{i}^{o}+r_{i}^{o}\right) \leqq T_{i}\left(\text { ただし }, t_{i}{ }^{o}=\hat{t}_{i}^{o}+\bar{t}_{i}^{o}\right)
$$

を満足する必要がある，また，得られた日程計画案が工 期的に実行可能であるためには,

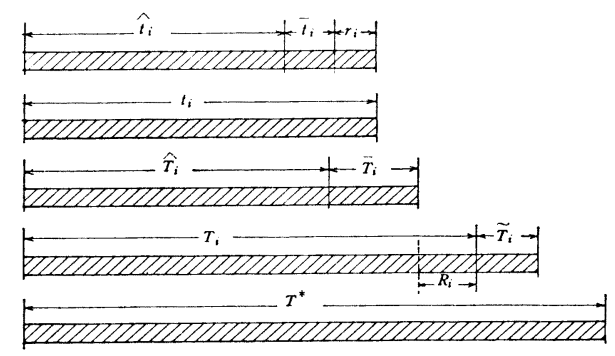

図一5 供用日数と土工工期との関係

$$
\max _{i}\left\{t_{i}^{o}+r_{i}^{o}+\tilde{T}_{i}\right\} \leqq T^{*}
$$

が成立しなければならない。

これらを満足しない場合には，まず土工機械系の運用 計画を十分考虑しながら遊休日数 $r_{i}{ }^{\circ}$ を減少させるよう に工程ネットワークの修正を検討する．しかしこのよう な手順のみではもはや式（25），(26）を満足する日程計 画案が得られないときは, 条件式 (21) の $H_{i}$ 值を少し小 さく変更してもら一度機械系割付けモデルを解き直す.

一方, 式 (25), (26) を満足する日程計画代替案は工 期的な実行可能性こそ保証されたが，供用日数が $t_{i}{ }^{o}$ か ら $t_{i}{ }^{o}+r_{i}{ }^{o}$ に増加したため遊休日数率 $\beta_{i}$ を新たに考慮 する必要が生じ, 結局機械系割付けモデルの目的関数式 は式 (16), (17) より,

$$
\begin{aligned}
& z_{1}\left(=z^{\prime}\right)=\sum_{i=1}^{m} \sum_{j=1}^{n}\left\{c_{i}+\left(1+\alpha_{i}+\beta_{i}\right) d_{i} / D_{i}\right\} \\
& \times\left(n_{i j} / N_{i j}\right)
\end{aligned}
$$

と変化するため, 土工機械系割付け計画としての最適性 を保証できなくなる場合が生じる.しかし，目的関数式 を式 (27) のように変更し, 改めて機械系割付けモデル を解き直すことは日程計画との整合性を欠くことになる ため,ここでは最適性が大きくくずれる場合のみ工程ネ ットワークの修正を検討することにする. 以上に述べた 土工機械系割付け計画のプロセスをフロー図で示したの が 図一6である.

\section{(3) 適用事例亡その考察}

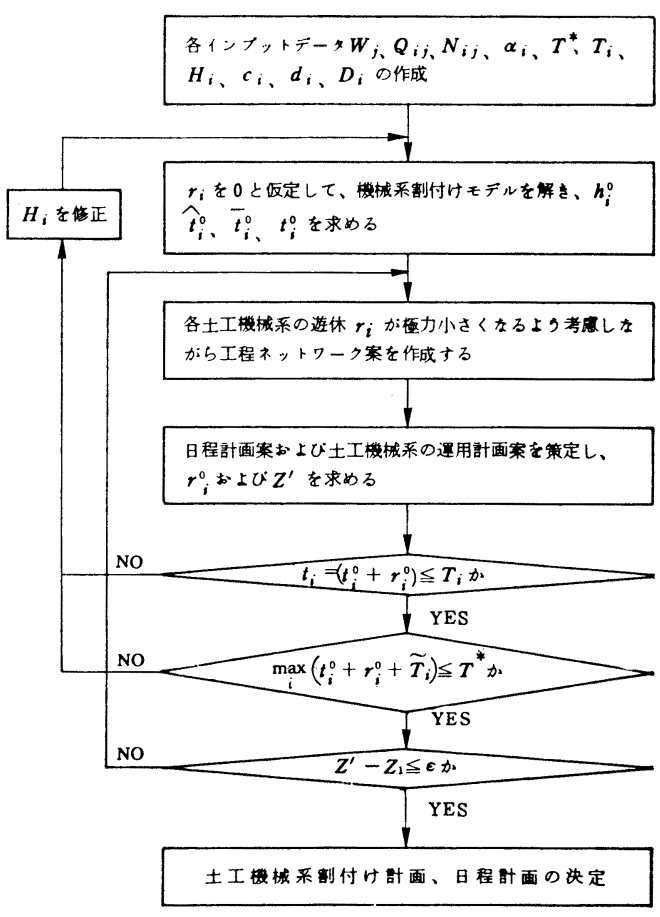

図一6 土工機械系割付け計画のフロー図 
表一2 投入土工機械系

\begin{tabular}{|c|c|c|c|c|c|c|}
\hline 機 械 系 番 号 & 1 & 2 & 3 & 4 & 5 & 6 \\
\hline 機 械 系 の 機 種. 台 数 & $\begin{array}{c}22 \mathrm{~m}^{3} \text { 級 } \mathrm{CS} \\
3 \text { 台 }\end{array}$ & $\begin{array}{c}12 \mathrm{~m}^{8} \text { 級 } \mathrm{CS} \\
3 \text { 台 }\end{array}$ & $\begin{array}{c}30 \mathrm{t} \text { 級 } \mathrm{BD} \\
1 \text { 台 }\end{array}$ & $\begin{array}{l}21 \mathrm{t} \text { 級 } \mathrm{BD} \\
3 \text { 台 }\end{array}$ & $\begin{array}{c}25 \mathrm{~m}^{3} \text { 級 } \mathrm{MS} \\
1 \text { 台 }\end{array}$ & $\begin{array}{c}16 \mathrm{~m}^{3} \text { 級 } \mathrm{MS} \\
1 \text { 台 }\end{array}$ \\
\hline $\begin{array}{l}\text { 時間当り機械経費 } c_{i} \text { (円/時) } \\
\text { 供用日当り機械経費 } d_{i} \text { (円/日) }\end{array}$ & $\begin{array}{l}15210 \\
29451\end{array}$ & $\begin{array}{r}9120 \\
15944\end{array}$ & $\begin{array}{l}12700 \\
22410\end{array}$ & $\begin{array}{r}7900 \\
12456\end{array}$ & $\begin{array}{l}32600 \\
61471\end{array}$ & $\begin{array}{l}22610 \\
38691\end{array}$ \\
\hline
\end{tabular}

注） CS：キャリオールスクレーパ, BD：フルドーザ, MS：モータスクレーパ

$\mathrm{CS}$ の経贅にはけん引用 $\mathrm{BD}$ を含み, MS の経費にはプッンャ用 $\mathrm{BD}$ を含む

a）土工機械系割付け計画代替案の作成

ここでは前節で提案した機械系割付けモデルを実際の 大規模土工に適用し，このような方法論の妥当性につい て検討する．なお，適用事例としては 3. と同一工事を 取上げることにする.

まず，クラスター分析モデルを適用した結果，当該工 事は 図一4 に示すように 77 個の単位作業によって構 成され，大部分が $50 \sim 300 \mathrm{~m}$ の短・中距離土工（平均 運土距離は $179 \mathrm{~m}$ ) であることが明らかとなった．そこ で本事例では 表一2 に示すような 6 種類の土工機械系 を想定することとし，以下では機械系割付けモデルのイ ンプットデータの作成方法について説明する.

(1) 機械経費 $c_{i}$ および $d_{i}:$ これらは式 (13), (14) に よって容易に求められる. その結果を示したのが 表一2 である。

(2) 時間当り運土回数 $N_{i j}$ : 土工機械系 $i$ で単位作業 $j$ を施工するときのサイクルタイムを $t_{i j}$ (分/回), 作 業効率を $E_{i j}$ とすれば，一般的に $N_{i j}$ は,

$$
N_{i j}=60 \times E_{i j} / t_{i j}
$$

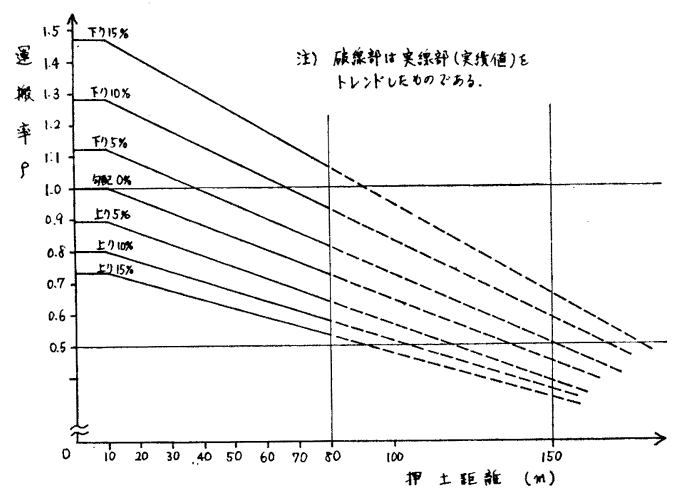

図一7ブルドーザの運搬率 $\rho$
として求まる.ここでは， $E_{i j}$ として標準的な 0.6 と いら值を用い, $t_{i j}$ に関しては一般的なサイクルタイム 算定式を用いた ${ }^{15)}$.

(3) 総運土量 $W_{j}$ : これは単位作業 $j$ を構成する各運 土作業の運土量和であり, 式（3）によってほぐした状 態に換算した値とする.

(4) 積載容量 $Q_{i j}$ : スクレーパの積載容量 $Q_{i j}$ は運 土距離や運土勾配の影響を受けないが，ブルドーザでは 押土板容量 $Q_{i j}$ が運土距離や運土勾配の 影響を受ける ことを考慮して次式のようにその值を計算した ${ }^{16)}$.

$$
Q_{i j}=\rho_{i j} \times B \times H^{2} / 2 \tan \varphi
$$

ここに, $B$ : 押土板幅 $(\mathrm{m}), H$ : 押土板高 $(\mathrm{m}), \varphi:$ 土 安息角 (40 度とする) であり, $\rho_{i j}$ は 図一7 で得られ る運搬率である。

(5) 作業不能日数率 $\alpha_{i}$ および総稼働可能時間 $H_{i}$ : ここでは作業不能日数 $\bar{T}_{i}$ が 0 という理想的な状態を考 え， $\alpha_{i}$ を 0 と仮定する. 次に $H_{i}$ は 図一5 および式 (16) から,

$$
H_{i}=\hat{T}_{i} \cdot D_{i}=\left(T_{i}-R_{i}-\bar{T}_{i}\right) \cdot D_{i}
$$

によって算定される. いま，図一5において $T_{i}$ を 220 日， $R_{i}$ を 40 日と仮定すれば $\tilde{T}_{i}$ は 180 日となる.し たがって， $D_{i}$ を 8 時間とすれば, 結局, 式 (30)より $H_{i}$ は 1440 時間となる. なお, 本事例では $T *$ を 280 日と想定する．これによって工期的には，

$$
T^{*}-\left(T_{i}+\tilde{T}_{i}\right)=60-\tilde{T}_{i}
$$

の余裕日数をもつものと考えた.

以上のようなインプットデータを用いて機械系割付け モデルを解いたところ, 表一3 のような結果を得た.

\section{b) 工程計画代替案の作成}

本適用例では，クラスター分析モデルによって 図一4 に示したような単位作業構成および施工工区分割案が得 られ，ついで機械系割付けモデルによって 表一3のよ

表一3 土工機械系割付け計画案

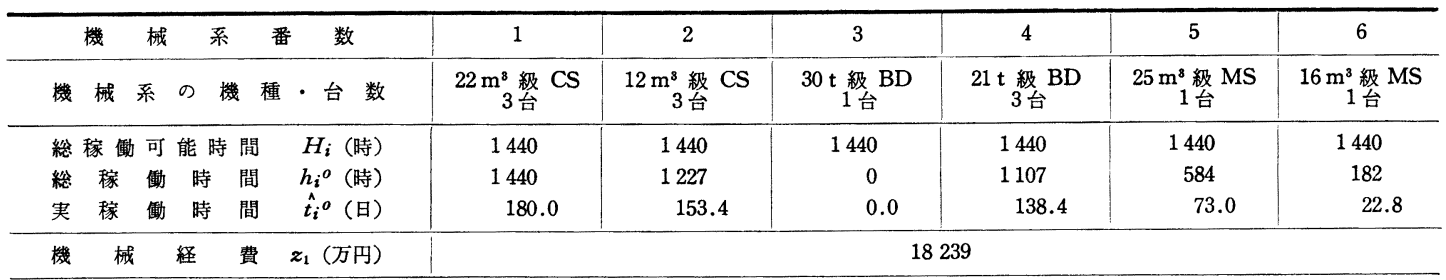


表一4 日程計画代替案の特性值

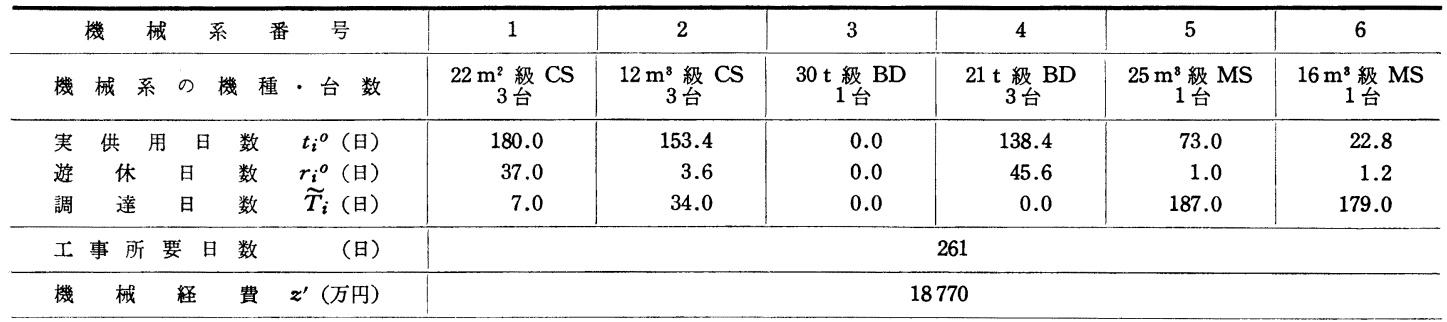

注）本事例では $\bar{T}_{i}=0$, すなわち $\bar{t}_{i}=0$ と考えているので, $t_{i}{ }^{o}=t_{i}{ }^{o}$ となる（式 (25) のカッコ内参照)

らな土工機械系割付け計画を得 た. そこで, 以下では 図一6の フローに従って工程計画案の作 成を試みる。

(i) エ区レベルの工程ネッ トワークの作成

まず，取付け道路に面した工

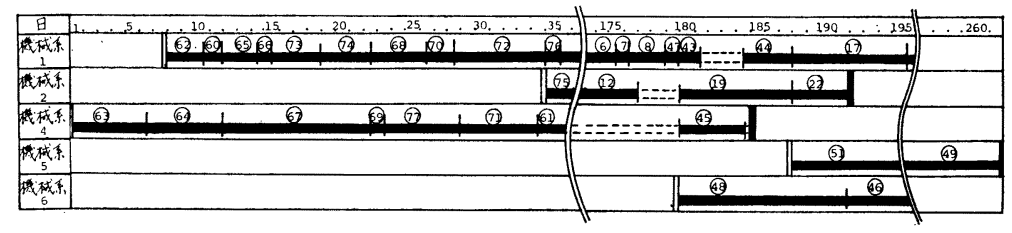

(○内の数字は単位作業番号, 11 は当該機械系の工事着工年月, 1は工事終了日を表わす)

図一9 日程計画案（土工機械系運用計画案）の一部
区A ししくは工区 B 第 1 工区と考え, 次に作業段取り 上隣接する工区へ順次移行すべきことから 図一4 の左 下方加右上方への $\mathrm{B} \rightarrow \mathrm{C}, \mathrm{C} \rightarrow \mathrm{E}, \mathrm{A} \rightarrow \mathrm{D}, \mathrm{D} \rightarrow \mathrm{F}$ と いら施工順序関係を想定した.さらに土工機械系の輻輳 を防ぐために，工区Eに関しては運土方向が工区 C と 交錯する単位作業群 $\mathrm{E}_{1}$ とそれ以外の $\mathrm{E}_{2}$ に分割し, $\mathrm{C} \rightarrow$ $\mathrm{E}_{1}, \mathrm{D} \rightarrow \mathrm{F} \rightarrow \mathrm{E}_{2}$ という施工順序が妥当であると判断し た. 以上によって工区レベルでの施工順序関係がある程 度明らかになったが，ここでは工期をできるだけ短縮す ることを目的として, 図一8のような並列型の工程ネッ トワーク代替案を作成した。

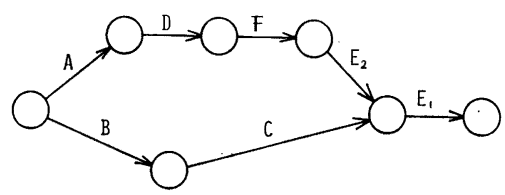

図一8 エ区レペルのエ程ネットワーク案

(ii) 単位作業レベルの工程ネットワークの作成 遊休日数 $r_{i}$ を減少することを目的として，(1) 技術的 に可能な限り同一工区内に複数の土工機械系を投入す る, (2) 施工中の工区内のすべての 単位作業が完了しな くても次工区が着手可能ならばその単位作業を着工す る,といら前提を設け, 単位作業をアクティビティとす る工程ネットワーク代替案を作成した. このようにして 得られた工程ネットワークに対して日程計画代替案を作 成し, 土工機械系の運用計画の形で示した結果の一部を 表わしたのが 図一9である. また, このときの $t_{i}{ }^{\circ}, r_{i}{ }^{\circ}$, $\tilde{T}_{i}$ の各值および工事所要日数ならびに機械経費 $z^{\prime}$ を 示したのが 表-4 である.

(iii) 実行可能性の検討および結果の考察

表一4より明らかなように, すべての土工機械系に対
して式 (25)，(26）が成立するため, 本日程計画代替案 は工期的に実行可能であることが明らかとなった.さら に, 表一3,4より, 日程計画作成の段階で発生した遊休 日数に関する機械経費の増加は 531 万円 $\left(=z^{\prime}-z_{1}\right)$, その増加率は $2.9 \%$ である. 本研究では, これを計画 目的達成上の許容範囲と判断することにする.

以上に述べた適用事例結果から次のような事柄が明ら かとなった。

(1) 土工機械系 3 は当該工事には不必要である. また 土工機械系 5,6 は施工すべき単位作業数 が少なく, そ れらを連続的に施工することが可能であるため遊休日数 も短かいが, 土工機械系 $1,2,4$ はほとんどすべての工 区の数多くの単位作業に投入されるため, 必然的に実稼 働日数, 遊休日数が長くなっている.

(2) 表一3 では土工機械系 1 の総稼働時間 $h_{1}{ }^{o}$ が総稼 働可能時間 $H_{1}$ と一致するが, これは土工機械系 1 のセ ット数を増加することが可能である場合には機械経費 $z_{1}$ をさらに低減できることを意味するものである. 事 実土工機械系 1 を 4 セットにすれば $z_{1}$ が 18091 万円 に減少した.

以上の適用事例およびその考察をとおして, 作業計画 および工程計画を客観的かつシステマティックに立案 し, 評価検討することを目的とした本研究の計画プロセ スの有効性が実証しえたものと判断する.

\section{5. 結}

本研究は, 近年ますます大規模化, 複雑化する傾向に ありながら，その計画構成要素を客観的に記述すること が困難であったために合理的な施工計画の作成方法が確 立していなかった大規模土工をとりあげて, その施工計 
画作成プロセスのシステム化に関するひとつのアプロー チを示したものである.

すなわち，まず大規模土工の施工計画作成プロセスを 図一1 のよらなプロセスフローとして表現し，次にその 中でも特にシステムズアプローチの遅れていた作業計画 および工程計画のプロセスに対して，クラスター分析お よび拡張型輸送問題を適用することにより，できるだけ 客観的で，かつシステマティックな計画代替案の立案な らびに評価検討が可能となるような方法を提案した.

図一1に示した 大規模土工の施工計画 システムのう ち, 土量配分計画に関しては各方面でシステム化が進ん でおり，また土工機械系選定情報の作成に関しても筆者 らはモンテカルロ・シミュレーションによる土工機械系 の稼働分析を試みている.したがって, これらの結果と 本研究の成果とを総合すれば大規模土工の施工計画シス テムに含まれるほとんどすべての計画プロセスがシステ ム化できたことになり，大型電子計算機を利用した効率 的な計画策定处理が可能になると考えられる.

しかし今後, 本研究を発展させるためには次のような 課題を考えていく必要がある.

（1）従来の工事実績ならびに現場技術者の経験・勘 を計画情報として 効率よくシステム内部に組込んでい $<$.

（2）各計画プロセスの最適化に固執することは計画 レベルとしての整合性を劣化させる可能性が強いため, 計画プロセス間の整合性を十分考虑しながら計画策定手 順を簡略化していくことを重視する.

（3）大規模土工では単位作業間の施工順序関係の決 定方法に関する自由度が大きいために, 本研究で提案し た工程ネットワークの作成プロセスは試行錯誤的な方法 の域を脱しきれなかった．そこで今後はこのプロセスに 対してもコンピュータの援用を前提とするグラフ理論な どの OR 手法の導入を検討する.

本研究を遂行するにあたり有益なご助言をいただいた 京都大学工学部 春名 攻助教授に謝意を表します. また
本研究は長尾正平氏 (現在, 東洋建設勤務) ならびに見 波 潔氏 (現在, 建設省勤務) の労に負らところが大で あり, 両君に贵心より感謝いたします.なお, 本稿は京 都大学審査学位論文の一部を要約したものである.

\section{参 考 文 献}

1）石川六郎：システムズアプローチによる工事管理, 鹿島 出版会, pp. 1 6, 1977.

2）春名 攻・山本幸司：大規模整地工事計画のシステム化 に関する研究, 土木学会論文報告集, 第 227 号, pp. 71 $\sim 84,1974$.

3）石川六郎：システムズアプローチによる工事管理, 鹿島 出版会, pp. 112 140, 1977.

4）吉川和広・山本幸司：アーランサービス循環待ち合わせ 系の解析法に関寸る一考察, 土木学会論文報告集, 第 243 号, pp. $71 \sim 80,1975$.

5）春名 攻・山本幸司：大規模整地工事計画のシステム化 に関寸る研究, 土木学会論文報告集, 第 227 号, pp. 71 $\sim 84,1974$.

6）吉川和広・山本幸司 - 長尾正平 : 大規模運土作業計画の システム化に関する研究, 土木学会関西支部年次学術講 演会概要, IV-36, 1976.

7) 奥野忠一ほか: 多変量解析法, 日科技連, pp. 391 411, 1971 .

8）特別講座 :「クラスターアナリシス」(1)〜(5), オペレー ションズリサーチ, 7 月号〜 11 月号, 1971.

9）吉川和広・山本幸司・見波 潔: 拡張型輸送問題を導入 した機械化土工計画システム, 土木学会全国大会年次学 術講演会概要, IV-147, 1971.

10）特集記事：「建設機械はこのように使われる」，建設機械， 1970 年 9 月号 1971 年 9 月号.

11）建設省大臣官房建設機械課編：建設機械等損料算定表 昭 和 48 年度版, 日本建設機械化協会, 1973.

12) 成久洋之: 拡張型輸送問題, 経営科学, 第 18 巻, 3,4 号, pp. 111 124, 1974.

13) Lourie, J.R. : Topology and Computation of the Generalized Transportation Problem, Management Science, Vol. 11, No. 1, pp. 177 187, 1964.

14) Eisemann, K. : The Generalized Stepping Stone Method for the Machine Loading Model, Management Science, Vol. 11, No. 1, pp. 154 176, 1964.

15）佐用泰司：機械化施工合理化の研究, 鹿島出版会, pp. 132 177, 1963.

16）特集記事 :「建設機械はこのように使われる」，建設機械， 1970 年 9 月号 1971 年 9 月号.

(1978.1.19 - 受付) 